\title{
STATUS HUKUM HAK MILIK ATAS TANAH WARGA NEGARA ASING DENGAN MEMINJAM NAMA WARGA NEGARA INDONESIA
}

\author{
Astri Putri Aprilla, Iwan Permadi, Lutfi Effendi \\ Program Studi Magister Kenotariatan Universitas Brawijaya \\ Jl.MT. Haryono 169 Malang \\ Email:astri1006@gmail.com
}

\begin{abstract}
This article described the consideration of judges who won the foreign citizen in disputes over land ownership and the agreement validity to borrow the names of a foreign citizen in ownership of land rights under Article 1320 of the Criminal Code. This study method used normative legal methods with a legislative approach, a case approach, and a philosophical approach. The results of the analysis showed that the judge who won the foreign citizen as the defendant for the ownership of the land by using the name of the plaintiff based his decision on the inadequacy of the evidence or legally the claimant has the land rights. Agreements made by a foreign citizen and Indonesian citizens are null and void because they did not fulfil the legal requirements of an agreement, namely the existence of a lawful cause. Land that was the object of a lawsuit couldn't be owned by a foreign citizen so that the land belongs to the state.
\end{abstract}

Keywords: land, agreement, Indonesia citizen, foreign citizen.

\begin{abstract}
Abstraks: Artikel ini mendeskripsikan pertimbangan hakim yang memenangkan warga negara asing dalam sengketa kepemilikan tanah dan keabsahan perjanjian pinjam nama warga negara asing dalam kepemilikan hak milik atas tanah berdasarkan Pasal 1320 Kitab Undang-Undang Hukum Perdata. Metode kajian ini menggunakan metode hukum normatif dengan pendekatan perundang-undangan, pendekatan kasus, dan pendekatan filosofis. Hasil analisis menunjukkan bahwa hakim yang memenangkan warga negara asing sebagai pihak tergugat atas kepemilikan tanah dengan menggunakan nama penggugat mendasarkan putusannya pada ketidakcukupan alat bukti pihak penggugat yang secara de jure memiliki hak atas tanah. Perjanjian yang dibuat oleh warga negara asing dan warga negara Indonesia batal demi hukum karena tidak memenuhi syarat sah suatu perjanjian, yaitu adanya sebab yang halal. Tanah yang menjadi obyek gugatan secara hukum tidak dapat dimiliki oleh warga negara asing sehingga tanah tersebut menjadi milik negara.
\end{abstract}

Kata kunci: tanah, perjanjian, warga negara Indonesia, warga negara asing

Tanah menjadi salah satu kebutuhan primer untuk menjadi prioritas dalam pemenuhannya, yakni dalam hal sebagai sarana untuk membangun sebuah hunian atau tempat tinggal maupun sarana investasi. Tanah sebagai benda tetap yang menjadi sarana investasi dinilai sangat menguntungkan, hal ini dikarenakan tanah memiliki nilai ekonomis yang meningkat dalam setiap tahunnya, oleh sebab itu harga tanah kian mahal dikarenakan banyaknya individu yang membutuhkan tanah. Peluang investasi inipun juga terbaca oleh banyak warga negara asing, sehingga menjadikan banyak dari warga negara asing berkunjung ke Indonesia untuk menanamkan investasi dan pada umumnya lebih banyak investasi ke tanah terutama di daerah yang dinilai berpotensi.

Investasi yang dilakukan oleh warga negara asing yang bersinggungan dengan tanah, menjadikan waktu mereka lebih banyak untuk berada di Indonesia dalam suatu kurun waktu tertentu, sehingga pada perkembangannya, pemerintah memfasilitasi hal tersebut dengan mengeluarkan seragam peraturan perundangundangan yang mengatur tentang warga negara 
asing yang memiliki hubungan khusus secara privat dengan tanah di Indonesia melalui hukum agraria sebagai payung hukum. Hukum tanah di Indonesia atau yang dikenal sebagai Hukum Agraria mengatur bahwa warga negara Indonesia boleh untuk memiliki tanah dengan alas hak milik yang kemudian dibuktikan dengan dikeluarkannya sertifikat hak milik atas tanah oleh Badan Pertanahan Nasional (BPN) (Arifuddin, Widhiyanti, dan Susilo, 2017:18), namun bagi warga negara asing dalam kegiatannya yang berlangsung di Indonesia dan berhubungan dengan pemanfaatan tanah Indonesia memberikan hak penguasaan berjangka waktu melalui hak pakai atas tanah ataupun hak sewa atas tanah. Ketentuan hak pakai atas tanah dan hak milik atas tanah tersebut diatur secara jelas pada UndangUndang Nomor 5 Tahun 1960 tentang Peraturan Dasar Pokok-Pokok Agraria (selanjutnya disebut dengan UUPA).

Berlandaskan amanat dari ketentuan UUPA terkait dengan hak pakai atas tanah yang dapat dimohonkan oleh warga negara asing maka pemerintah mengeluarkan Peraturan Pemerintah Nomor 40 Tahun 1996 tentang Hak Guna Bangunan, Hak Guna Usaha dan Hak Pakai atas Tanah (selanjutnya disebut sebagai PP No. 40 Tahun 1996), terkhusus pada Pasal 39 terkait dengan subjek hak pakai atas tanah yang menjadikan warga negara asing sebagai salah satu subjek penerima hak pakai atas tanah. Peraturan Pemerintah ini dinyatakan masih berlaku sampai dengan sekarang. Pasal 42 UUPA dan Pasal 39 PP No. 40 Tahun 1996 mengatur bahwa warga negara asing yang berkedudukan di Indonesia dapat menjadi subjek dari hak pakai atas tanah. Hak pakai atas tanah yang diatur secara spesifik pada PP No. 40 Tahun 1996 memberikan batasan jangka waktu selama rentang 25 (dua puluh lima) tahun sejak sertifikat hak pakai atas tanah dikeluarkan. Jangka waktu yang diberikan oleh ketentuan hukum agraria terkait hak pakai atas tanah ini kemudian dirasa oleh banyak warga negara asing masih belum cukup untuk pelaksanaan segala kegiatannya yang berlangsung di Indonesia yang berhubungan dengan tanah, maka terjadilah beberapa usaha-usaha untuk melegalkan lamanya jangka waktu hak pakai atas tanah yang sedang dikuasai melalui serentetan perjanjian yang melibatkan warga negara Indonesia khususnya warga lokal suatu daerah tersebut.

Serentetan usaha untuk melegalkan yang dimaksud adalah dengan dibuatnya perjanjian- perjanjian untuk mendapatkan jangka waktu lebih lama dari yang ditentukan, yakni dengan dilakukannya jual beli tanah melalui mekanisme pinjam nama warga negara Indonesia oleh warga negara asing. Perjanjian ini melibatkan warga negara asing yang memiliki uang untuk membeli sebuah bidang tanah yang kemudian diatasnamakan warga negara Indonesia pada sertifikat hak milik, namun sebelumnya di antara warga negara Indonesia dan warga negara asing akan diikat oleh perjanjian-perjanjian yang lain, yakni perjanjian utang-piutang, perjanjian sewa menyewa, akta kuasa dan sebagainya yang dibuat secara autentik dihadapan seorang Notaris, yang memang berwenang untuk membuat akta autentik berdasarkan Undang-Undang Nomor 2 Tahun 2014 tentang Perubahan Atas Undang-Undang Nomor 30 Tahun 2004 tentang Jabatan Notaris (selanjutnya disebut sebagai UU Jabatan Notaris).

Faktanya banyak terjadi jual beli tanah melalui sistem perjanjian pinjam nama antara warga negara Indonesia dan warga negara asing, dimana bisa saja salah satu pihak tidak lagi beritikad baik untuk meneruskan isi dari perjanjian tersebut dan berpindah haluan untuk menguasai objek perjanjian secara utuh dan individual. Jual beli tanah sendiri yang dilakukan oleh warga negara asing menurut hukum agraria tidak dapat dilakukan, karena warga negara asing tidak diperbolehkan untuk memiliki tanah di Indonesia dengan alas hak milik. Kepemilikan tersebut menyalahi asas nasionalitas/ asas kebangsaan yang menjadi salah satu asas dalam UUPA. Asas nasionalitas menjelaskan bahwa hanya warga negara Indonesia lah yang boleh untuk memiliki tanah di Indonesia, tercantum dalam Pasal 21 UUPA. Melalui perjanjian pinjam nama inilah kemudian jual beli tanah menggunakan nama warga negara Indonesia dapat dilaksanakan dengan sejumlah dana yang berasal dari warga negara asing sebagai pembayaran atas sebuah bidang tanah tersebut.

Penyalahgunaan perilaku tersebut akhirnya banyak menimbulkan konflik yang kemudian diselesaikan melalui gugatan di pengadilan, dengan pihak yang bersengketa adalah warga negara Indonesia melawan warga negara asing. Seperti pada contoh kasus yang terjadi di Bali pada putusan register perkara no. 328/Pdt.G/2013/PN.DPS, dimana warga negara Indonesia sebagai penggugat menggugat warga negara asing sebagai tergugat terkait dengan kepemilikan tanah yang dilakukan oleh tergugat menyalahi asas 
nasionalitas. Secara de jure hak kepemilikan atas tanah tersebut adalah milik warga negara Indonesia karena nama yang tercantum pada sertifikat hak milik adalah nama dari warga negara Indonesia yang bersangkutan, namun secara de facto yang memiliki tanah adalah warga negara asing, hal ini diungkapkan pada sidang di pengadilan.

Penggugat juga menggugat tergugat atas perlakuan pemaksaan dan tipu muslihat pada saat pelaksanaan perjanjian-perjanjian tersebut dan mendalilkan bahwasanya penggugat adalah seorang yang awam hukum, namun kuasa hukum tergugat menampik hal itu dan menjelaskan tidak mungkin penggugat adalah orang yang awam hukum tetapi dapat mengarahkan untuk dapat membuat perjanjian dengan suatu rincian yang terperinci. Hakim pada putusannya menolak seluruh gugatan penggugat untuk keseluruhan dan memenangkan warga negara asing, karena warga negara asing dapat menunjukkan serangkaian bukti yang mendukung di persidangan. Rumusan masalah dalam kajian ini adalah: 1 Bagaimana pertimbangan hakim pada putusan yang memenagkan warga negara asing dalam sengketa kepemilikan hak atas tanah? 2. Bagaimana perjanjian pinjam nama warga negara asing dalam kepemilikan hak milik atas tanah berdasarkan pasal 1320 kitab undang-undang hukum perdata.

\section{METODE}

Metode yang digunakan dalam kajian ini menggunakan metode hukum normatif dengan pendekatan perundang-undangan, pendekatan kasus dan pendekatan filosofis. Pendekatan perundang-undangan dimana akan menganalisa pada ketentuan Pasal-pasal terkait dengan asas nasionalitas dan penguasaan tanah oleh warga negara asing yang terdapat pada Undang-Undang Nomor 5 Tahun 1960 tentang Peraturan Dasar Pokok-Pokok Agraria dan Peraturan Pemerintah Nomor 40 Tahun 1996 tentang Hak Guna Bangunan, Hak Guna Usaha dan Hak Pakai Atas Tanah, pendekatan kasus digunakan karena pada penelitian ini berfokus pada suatu putusan pengadilan yang pada putusannya hakim memenangkan warga negara asing dan pendekatan filsafat digunakan sebagai pisau analisis untuk mencari hakikat kebenaran dari asas nasionalitas yang terkandung pada UndangUndang Nomor 5 Tahun 1960 tentang Peraturan Dasar Pokok-Pokok Agraria bahwa hanya warga negara Indonesia yang boleh memiliki hak milik atas tanah.

Kajian menggunakan metode analisa gramatikal dan hermeunetika hukum, dimana metode gramatikal digunakan untuk menafsirkan makna dari peraturan perundang-undangan dan metode hermeneutika hukum digunakan untuk menganalisa mencari kebenaran yang hakikat berdasarkan falsafati dari asas nasionalitas pada Undang-Undang Nomor 5 Tahun 1960 tentang Peraturan Dasar Pokok-Pokok Agraria.

\section{HASIL DAN PEMBAHASAN}

\section{Pertimbangan Hakim pada Putusan yang Memenagkan Warga Negara Asing dalam Sengketa Kepemilikan Hak Atas Tanah}

Putusan pengadilan adalah sebuah produk pengadilan yang dihasilkan dari adanya suatu gugatan yang diajukan. Sebuah gugatan, terkhusus yang masuk pada ranah lingkup peradilan perdata, maka wajib mengikuti alur bagaimana laiknya sebuah peradilan perdata berjalan dengan memperhatikan segala ketentuan dan asas hukum acara perdata. Putusan yang menjadi objek dalam kajian ini adalah putusan dengan register perkara no. 328/Pdt.G/2013/PN.DPS. Gugatan tersebut didasarkan atas dalil penggugat (berkebangsaan warga negara Indonesia) yang menggugat tergugat (warga negara asing) terhadap kepemilikan objek sengketa yang secara de jure adalah milik dari warga negara Indonesia yang dibuktikan dengan terteranya nama warga negara Indonesia tersebut pada sertifikat hak milik atas tanah. Penggugat menginginkan agar tanah tersebut diakui secara sah menurut hukum adalah miliknya dan memohon kepada hakim untuk membatalkan segala perjanjian yang telah dibuat dihadapan di notaris bersama dengan tergugat. Berdasarkan permintaan tersebut maka menurut hukum pembuktian perdata, penggugat harus dapat menunjukkan alat bukti untuk menguatkan dalilnya di persidangan. Menurut Pasal 1866 Kitab Undang-Undang Hukum Perdata (selanjutnya disebut sebagai KUHPerdata), alat bukti dalam perkara perdata antara lain adalah tulisan, saksi, persangkaan, pengakuan dan sumpah. Bukti-bukti itu harus dinilai oleh hakim di dalam memutus setiap perkara yang diajukan kepadanya (Salim dan Erlies, 2016:215) dan hakim harus menemukan dan menentukan peristiwanya atau hubungan hukumnya dan kemudian memperlakukan 
atau menerapkan hukumnya terhadap peristiwa yang telah ditetapkannya itu. Peristiwa yang relevan yang harus ditetapkan dan harus dibuktikan, karena siapa yang mengaku mempunyai maka harus membuktikannya (Mertokusumo, 2010:190).

Alat bukti yang terpenting dalam proses peradilan perdata adalah bukti tulisan, namun yang memiliki kekuatan pembuktian istimewa adalah akta autentik (Sarwono, 2011:244). Letak pembuktian istimewa dari akta autentik sesuai Pasal 1870 KUHPerdata, akta autentik memberi pihak dan ahli waris atau orang lain yang memungkinkan mendapat hak dari mereka atas bukti yang sempurna tentang yang termuat di dalamnya. Akta autentik adalah bukti yang "mengikat", bahwa yang ditulis dalam akta harus dipercaya Hakim, harus dianggap benar, selamanya ketidak-benarannya dapat dibuktikan, dan ia memberikan suatu bukti sempurna, sudah tidak diperlukan lagi bukti tambahan. Ia merupakan suatu alat bukti yang mengikat dan sempurna.

Putusan pengadilan yang menjadi objek kajian menolak gugatan penggugat secara keseluruhan dan menyatakan bahwa penggugat adalah sebagai pihak yang dikalahkan, karena pihak penggugat dianggap tidak dapat menunjukkan alat bukti yang dapat menguatkan dalil gugatannya menurut ketentuan beracara dalam peradilan perdata. Pembuktian dibebankan kepada penggugat dikarenakan tergugat membantah dalil gugatan penggugat bahwa telah terjadi penipuan, tipu muslihat maupun kekhilafan dalam melakukan perjanjian yang dibuat dihadapan notaris, dan untuk menguatkan sanggahannya tergugat telah mengajukan bukti-bukti berupa suratsurat dan saksi. Bukti-bukti berupa perjanjian dalam bentuk minuta asli dan saksi dibawa oleh tergugat ke persidangan, sehingga hal tersebut menjadi dasar pertimbangan bagi hakimuntuk memutuskan perkara dan menyatakan pihak penggugat sebagai pihak yang kalah di persidangan, dengan adanya bukti tulisan berupa akta autentik yang memiliki kekuatan pembuktian sempurna maka kemudian menjadikan pihak tergugat menang dalam persidangan.

Terhadap adanya suatu putusan pengadilan dianggap telah memberikan adanya suatu keadilan bagi masing-masing pihak yang berperkara. Suatu keadilan yang didapatkan oleh masing-masing pihak adalah keadilan yang diberikan berdasarkan usaha dari masing-masing pihak dalam melakukan pembuktian di pengadilan di muka hakim. Keadilan yang demikian dikenal dengan keadilan distributif, dimana keadilan distributif menitik-beratkan pada keadilan yang diterima oleh masing-masing pihak berdasarkan besarnya jasa atau prestasi yang telah dilakukan oleh masing-masing pihak, sehingga masing-masing pihak dianggap telah setuju dan sepakat untuk menerima hasil putusan hakim tersebut.

Perkara tersebut dapat dikatakan memperkarakan terkait dengan keabsahan perjanjian dan keabsahan sertifikat hak milik terkait dengan kepemilikan tanah yang sebenarnya. Perjanjian yang terjadi di antara warga negara Indonesia sebagai penggugat dan warga negara asing sebagai tergugat adalah suatu perjanjian yang dibuat secara akta autentik dihadapan seorang pejabat umum tertentu yang memiliki kewenangan berdasarkan amanat undang-undang.

Perjanjian-perjanjian yang mengikat antara penggugat dan tergugat adalah perjanjian yang dibuat dalam bentuk akta autentik dihadapan notaris. Notaris dalam kompetensinya untuk membuat suatu akta autentik adalah berdasar kewenangan yang diberikan Pasal 15 UU Jabatan Notaris. Dalam hal ini notaris sebagai pejabat umum berwenang untuk membuat akta autentik yang terikat dalam ketentuan hukum perdata menurut KUHPerdata terkhusus dalam hukum pembuktian. Notaris adalah sebagai perpanjangan tangan dari kehendak para pihak yang mengahadap untuk kemudian diminta membuat akta. Pada kasus putusan tersebut juga melibatkan seorang Notaris sebagai turut tergugat karena dianggap telah membantu tergugat dalam melakukan penyelundupan hukum dalam hal kepemilikan tanah di Indonesia oleh warga negara asing. Namun jika ditinjau dari segi aspek kewenangan yang dimiliki oleh notaris dalam membuat perjanjian, maka akta-akta perjanjian yang dibuat dihadapan notaris dengan dihadiri oleh para pihak, maka menjadikan akta-akta tersebut adalah akta autentik dan sah menurut hukum yang berlaku di Indonesia. Akta-akta tersebut menjadi autentik dikarenakan akta-akta tersebut telah memenuhi unsur yang disebutkan pada Pasal 1868 KUHPerdata terkait dengan hakikat akta autentik, yaitu akta yang dalam bentuk yang ditentukan oleh undang-undang, dibuat oleh atau di hadapan pegawai-pegawai umum yang berkuasa untuk itu di tempat di mana akta dibuatnya. Bukti akta autentik yang dibuat dihadapan atau oleh notaris memiliki kekuatan pembuktian lahiriah, formil dan materiil (Sjaifurrachman dan Adjie, 2011:166).

Menurut hukum pembuktian perdata, bahwa di dalam gugatan saja tidak cukup hanya 
disebutkan peristiwa hukum yang menjadi dasar tuntutan saja, namun juga turut pula disebutkan kejadian-kejadian nyata yang mendahului peristiwa hukum yang menjadi dasar gugatan dan yang menjadi sebab timbulnya peristiwa hukum tersebut (Salim dan Erlies, 2016:224), maka penggugat dalam hal ini harus dapat menunjukkan bukti nyata terkait beberapa peristiwa yang terjadi pada beberapa waktu lalu saat bersama dengan tergugat bersama-sama untuk membuat perjanjianperjanjian di hadapan Notaris. Hal ini diperlukan agar pengajuan alat bukti dari sisi penggugat dapat dijadikan bahan pertimbangan bagi hakim dalam memutus perkara sehingga pada putusannya nanti akan meringankan penggugat itu sendiri. Faktanya penggugat tidak dapat menunjukkan bukti apapun dalam persidangan untuk menguatkan dalil gugatannya kepada tergugat sehingga hakim akhirnya menyatakan penggugat sebagai pihak yang kalah, karena pembuktian adalah suatu hal yang penting dalam persidangan.

Putusan yang memenangkan warga negara asing sebagai tergugat tersebut apabila ditinjau dari sisi keadilan, maka dapat dikatakan sebagai sebuah keadilan yang didapat tergugat sesuai dengan porsi usahanya dalam membuktikan kebenaran di persidangan sesuai dengan konsep keadilan distributif (Salim dan Erlies, 2014:26) yang dikemukakan oleh Aristoteles. Hakim dalam putusannya memenangkan tergugat dan menyatakan penggugat kalah adalah dalam porsi pembuktian yang telah dilakukan oleh kedua belah pihak, dari pembuktian tersebutlah hakim menilai pihak mana yang lebih kuat dalam memiliki buktibukti yang dapat menguatkan dalil maupun sanggahan pada saat di persidangan. Saat memutus perkara hakim pun berusaha untuk bertindak adil yang diharapkan dapat mendatangkan kebahagian bagi kedua pihak, sehingga dalam hal ini pun hakim memperhatikan aspek keadilan korektif, karena hakim dengan kompetensi hukum yang dimiliki dapat menyelesaikan sengketa diantara para pihak. Berbicara mengenai keadilan adalah suatu hal yang relatif yang dirasakan berbeda oleh tiap individu, terlebih terkait dengan keadilan yang berasal dari putusan hakim. Saat dirasa telah adil maka segala sesuatunya akan selesai, namun apabila dirasa tidak adil maka hukum memberikan upaya hukum yang dapat ditempuh terkait dengan putusan tersebut yakni banding, kasasi hingga peninjauan kembali.
Terkait dengan isi putusan tersebut adalah bahwa penggugat menggugat tergugat telah melakukan penipuan, tipu muslihat bahkan kekhilafan kepada penggugat untuk dapat menanda-tangani beberapa perjanjian guna melegalkan penguasaan tanah oleh tergugat di Indonesia. Hukum agraria mengatur bahwa hanya warga negara Indonesia yang boleh memiliki tanah di Indonesia secara hak milik, hal tersebut adalah sesuai dengan asas nasionalitas/asas kebangsaan berdasarkan amanat Undang-Undang Nomor 5 Tahun 1960 tentang Peraturan Dasar PokokPokok Agraria (selanjutnya disebut sebagai UUPA) pada Pasal 1 ayat (3) dan Pasal 21. Pada kedua pasal tersebut dijelaskan bahwa hubungan antara bangsa Indonesia dengan bumi, air dan ruang angkasa adalah suatu hubungan yang bersifat abadi. Namun UUPA memberikan kesempatan pada warga negara asing untuk dapat mengusahakan tanah di Indonesia dengan memberikan alas hak penguasaan berupa hak pakai dan hak sewa.

UUPA mengatur bahwa Warga negara asing sebagai salah satu subjek penerima hak pakai dengan ketentuan jangka waktu selama 25 (dua puluh lima) tahun menurut Pasal 42 UUPA dan Pasal 39 Peraturan Pemerintah Nomor 40 Tahun 1996 tentang Hak Guna Bangunan, Hak Guna Usaha dan Hak Pakai atas Tanah (selanjutnya disebut sebagai PP No. 40 Tahun 1996). Adanya jangka waktu inilah yang kemudian ingin disiasati oleh hampir sebagian warga negara asing yang berkedudukan di Indonesia agar dapat lebih lama lagi mengusahakan tanah di Indonesia lebih dari 25 (dua puluh lima) tahun. Penyiasatan yang dilakukan oleh warga negara asing adalah dengan membuat perjanjian dengan warga negara Indonesia yang nantinya namanya akan dipinjam sebagai pemilik sah dari tanah tersebut pada sertifikat hak milik atas tanah. Perjanjian ini untuk kemudian dikenal sebagai perjanjian pinjam nama.

Perjanjian pinjam nama yang dilakukan oleh penggugat dan tergugat adalah termasuk dalam perjanjian yang tidak diatur didalam KUHPerdata atau disebut sebagai perjanjian innominaat. Perjanjian innominaat sendiri tidak dilarang dalam penerapannya sehari-hari karena perjanjian ini adalah jenis perjanjian yang tumbuh dan berkembang di budaya masyarakat dimana banyak ditemui perjanjian-perjanjian lainnya yang tidak diatur oleh KUHPerdata namun berdasarkan kesepakatan di antara para pihak. Berdasarkan 
kesepakatan para pihak inilah yang kemudian melahirkan hubungan terikatnya para pihak terhadap isi dari perjanjian itu sendiri sesuai dengan Pasal 1338 ayat (1) KUHPerdata bahwa perjanjian berlaku sebagai undang-undang bagi para pihak.

Hadirnya perjanjian innominaat adalah suatu bentuk bahwa Buku III KUHPerdata menganut asas terbuka. Dikatakan terbuka karena setiap orang atau pihak yang hendak membuat perjanjian diberi kebebasan untuk membuat perikatan yang mengatur hubungan hukum mereka tentang apa saja dan dalam bentuk apa saja asalkan tidak bertentangan dengan undang-undang (Sugianto, 2014:3). Selain itu Buku III KUHPerdata juga memiliki sifat sebagai hukum pelengkap, artinya bahwa pasal-pasal hukum KUHPerdata boleh dikesampingkan oleh para pihak jika mereka mengehendakinya.

\section{Perjanjian Pinjam Nama Warga Negara Asing dalam Kepemilikan Hak Milik Atas Tanah Berdasarkan Pasal 1320 Kitab Undang- Undang Hukum Perdata}

Perjanjian yang tidak diatur dalam KUHPerdata diperbolehkan selagi tidak menyalahi ketentuan Pasal 1320 KUHPerdata terkait dengan syarat sahnya perjanjian yang mencakup 4 (empat) aspek syarat sahnya, yakni: sepakat, cakap, suatu hal tertentu dan sebab yang halal, dan tidak pula menyalahi ketentuan undang-undang, norma sosial dan kesusilaan. Namun perjanjian pinjam nama sendiri yang kemudian digunakan untuk melegalkan penguasaan tanah dalam kurun waktu yang lama oleh warga negara asing sebagai usaha untuk menyimpangi aturan hukum yang berlaku pada hukum agraria dapat dianggap sebagai usaha penyelundupan hukum dan hal tersebut sangat jelas dilarang. Dimana esensi dari perjanjian pinjam nama ini akan mencantumkan nama dari warga negara Indonesia sebagai pemilik tanah pada sertifikat hak milik (kepemilikan tanah secara de jure) namun kenyataannya yang memiliki dan mengusahakan tanah tersebut adalah warga negara asing (kepemilikan tanah secara de facto). Lalu kepemilikan tanah tersebut akan dibuat sah dan legal secara hukum dengan dibalut serangkaian perjanjian yakni perjanjian utang-piutang, sewa menyewa dan akta kuasa, yang pada intinya warga negara asing sebagai pihak yang mengusahakan tanah yang dimiliki oleh warga negara Indonesia.
Serangkaian perjanjian-perjanjian ini oleh penggugat dan tergugat dibuat dihadapan notaris. Notaris berwenang untuk membuat akta autentik berdasarkan kewenangan yang diberikan oleh UU Jabatan Notaris secara atribusi yang kemudia diimplementasikan pada keberlakukan Pasal 15 UU Jabatan Notaris. Berdasar kewenangan ini maka keabsahan akta yang dibuat oleh notaris memiliki kekuatan pembuktian lahiriah, formal dan materiil, sehingga memiliki kekuatan hukum yang kuat sebagai alat pembuktian di persidangan perdata. Selain pada kewenangan yang dimiliki oleh Notaris sebagai pejabat umum yang berwenang untuk membuat suatu akta autentik, kewenangan juga dimiliki secara privat oleh para pihak yang diberikan secara atribusi oleh KUHPerdata melalui keberlakuan Pasal 1320 KUHPerdata pada syarat subjektif, yakni terkait adanya sepakat dan cakap. Kewenangan yang diberikan oleh KUHPerdata melalui syarat "cakap" pada Pasal 1320 KUHPerdata adalah merujuk pada kompetensi individiual para pihak dalam membuat suatu perjanjian. Indikator seseorang dikatakan cakap adalah ketika telah berusia 18 tahun atau telah menikah dan tidak dalam pengampuan. Terpenuhinya syarat "cakap" maka memberikan kewenangan kepada individu untuk dapat membuat perjanjian dan mengikatkan dirinya kepada orang lain untuk patuh terhadap substansi isi perjanjian dengan kesadaran penuh serta tanggung jawab terhadap pemenuhan isi perjanjian tersebut.

Suatu akta yang dibuat dihadapan atau oleh seorang Notaris dan memenuhi ketentuan suatu akta autentik menurut Pasal 1868 KUHPerdata maka akta tersebut dapat dikatan adalah sebuah akta autentik. Akta autentik memiliki kekuatan pembuktian, lahiriah formil dan materil. Dikarenakan akta autentik memiliki kekuatan hukum pembuktian yang demikian, maka apabila suatu akta disanggah kebenarannya oleh suatu pihak, maka pihak yang menyanggah tersebut haruslah membuktikan letak dimana ketidakbenaran dari suatu akta yang disanggahnya. Hal yang demikian dinamakan sebagai asas praduga sah terhadap suatu akta.

Meninjau dari aspek keabsahan perjanjian yang dibuat oleh para pihak (warga negara asing dan warga negara Indonesia) maka dikatakan perjanjian-perjanjian tersebut tidak memenuhi syarat sahnya perjanjian pada Pasal 1320 KUHPerdata pada point yang terkait "sebab yang halal", sehingga menjadikan perjanjian tersebut 
dikatakan telah batal demi hukum. Batalnya demi hukum perjanjian ini diakibatkan tidak dipenuhinya syarat objektif pada syarat sahnya perjanjian yakni suatu hal tertentu ataupun sebab yang halal, yang dalam kasus ini adalah sebab yang halal dan kebatalan atas akta tersebut tidak perlu dimintakan ke pengadilan, namun pada putusan ini sama sekali tidak membahas lebih lanjut tentang bagaimana keabsahan dari perjanjian-perjanjian tersebut.

Perjanjian yang telah batal maka tidak memiliki akibat hukum apapun dan dianggap tidak pernah ada perjanjian. Berdasar hukum positif Indonesia, maka tidak dibenarkan warga negara asing memiliki tanah hak milik walaupun melalui mekanisme perjanjian pinjam nama dengan warga negara Indonesia, karena perjanjian yang digunakan sebagai landasan pun juga tidak memiliki kekuatan hukum.

\section{SIMPULAN}

1. Putusan pengadilan menolak gugatan penggugat secara keseluruhan dan menyatakan bahwa penggugat adalah sebagai pihak yang dikalahkan. Perjanjian pinjam nama yang dilakukan oleh penggugat dan tergugat adalah termasuk dalam perjanjian yang tidak diatur didalam KUHPerdata atau disebut sebagai perjanjian innominaat. Perjanjian innominaat

\section{DAFTAR RUJUKAN}

Arifuddin, A., Widhiyanti, H., \& Susilo, H. (2017). Implikasi Yuridis Terhadap Pejabat Pembuat Akta Tanah Penerima Kuasa Menyetor Uang Pajak Penghasilan/Bea Perolehan Hak Atas Tanah Dan Bangunan Dari Wajib Pajak. Jurnal Ilmiah Pendidikan Pancasila dan Kewarganegaraan, 2 (1).

Mertokusumo, Sudikno. 2010. Hukum Acara Perdata Indonesia. Yogyakarta: Universitas Atma Jaya Yogyakarta.

Peraturan Pemerintah Nomor 40 Tahun 1996 tentang Hak Guna Bangunan, Hak Guna Usaha dan Hak Pakai atas Tanah

Salim, HS dan Nurbani, Erlies Septiana. 2014. Penerapan Teori Hukum Pada Penelitian Disertasi dan Tesis Buku Kedua., Jakarta: PT Raja Grafindo Persada. sendiri tidak dilarang dalam penerapannya sehari-hari karena perjanjian ini adalah jenis perjanjian yang tumbuh dan berkembang di budaya masyarakat dimana banyak ditemui perjanjian-perjanjian lainnya yang tidak diatur oleh KUHPerdata namun berdasarkan kesepakatan di antara para pihak

2. Kepemilikan tanah secara de facto adalah milik warga negara asing walaupun secara de jure menggunakan nama warga negara Indonesia. Kenyataan ini berdasarkan hukum agraria yang menganut asas nasionalitas/asas kebangsaan tidak memperbolehkan warga negara asing memiliki tanah di Indonesia, sehingga untuk kemudian status hukum dari tanah tersebut menurut ketentuan Pasal 26 ayat (2) UUPA adalah batal karena hukum dan tanahnya jatuh kepada negara, dengan ketentuan bahwa hak-hak pihak lain yang membebaninya tetap berlangsung serta semua pembayaran yang telah diterima oleh pemilik tidak dapat dituntut kembali. Jatuhnya tanah objek sengketa tersebut ke negara menjadikan sertifikat hak milik yang atas nama warga negara Indonesia batal demi hukum dan untuk kemudian tanah tersebut dapat dimohonkan hak kepemilikannya oleh orang lain selain dari warga negara Indonesia.
2016. Penerapan Teori Hukum Pada

Disertasi dan Tesis Buku Ketiga. Jakarta: PT Raja Grafindo Persada.

Sarwono. 2011. Hukum Acara Perdata Teori dan

Praktik. Jakarta: Sinar Grafika Sjaifurrachman dan Adjie, Habib. 2011. Aspek Pertanggungjawaban Notaris Dalam Pembuktian Akta. Bandung: Mandar Maju.

Subekti, R. 2001. Hukum Pembuktian. Jakarta: PT. Pradnya Paramita.

Sugianto, Fajar. 2014. Hukum Kontrak Teori dan Praktik Pembuatan Kontrak. Malang: Setara Press.

Undang-Undang Nomor 5 Tahun 1960 tentang Peraturan Dasar Pokok-Pokok Agraria.

Undang-Undang Nomor 2 Tahun 2014 tentang Perubahan Atas Undang-Undang Nomor 30 Tahun 20014 tentang Jabatan Notaris. 